\title{
Under the background of "Internet Plus", the innovation of the training mode of tourism management professionals in higher vocational colleges is discussed
}

\author{
Zichao Liao $^{1}$ \\ ${ }^{1}$ Jiangxi Taihao Animation Vocational College Jiangxi Nanchang 330200
}

\begin{abstract}
With the continuous development of society, China's Internet science and technology and computer information technology are also developing and progressing. In this process, Internet technology has had a great impact on many professional fields, Internet technology has become an indispensable part of people's lives. With the concept of "Internet Plus", various industries have set off a trend about the combination of the Internet and traditional fields. The field of education is no exception, in the "Internet plus" background of the field of education has also set off a wave of reform, the current teaching of vocational colleges and universities are gradually combined with Internet technology. The traditional offline teaching concept and teaching method can not meet the needs of tourism management talents in the society at the time. Therefore, under the background of the Internet, the combination of education and the Internet is an inevitable trend, in the training of tourism management professionals in domestic vocational colleges, Internet technology has greatly promoted the training of tourism professionals. Therefore, this paper mainly revolves around the innovative development of the training mode of tourism management personnel in higher vocational colleges under the background of "Internet plus", and hopes that this paper can provide a reference for the research on the training mode of tourism management professionals in higher vocational education.
\end{abstract}

\section{The INFLUENCE OF TOURISM MANAGEMENT MAJORS IN HIGHER Vocational Colleges Under THE BACKGROUND OF "INTERNET PLUS"}

Under the background of "Internet Plus", the field of higher education has been hit like never before, and it is also facing many opportunities in teaching. At the same time, the development and progress of Internet technology also need teachers in the teaching process to update their own educational ideas and teaching methods to keep up with the pace of the development of the times, in line with the trend of the development of the times. In the current domestic teaching and training innovation of tourism management major, it is more necessary for educators to actively change the traditional educational concept, to combine the Internet with teaching, so as to promote the reform and innovation of tourism management major in teaching.

\subsection{The application of "Internet Plus" plays a fundamental role in the teaching of tourism management}

In the teaching of tourism management majors in today's colleges and universities, we should not only cultivate students' theoretical knowledge of the profession, but also pay attention to practical ability. The emergence of the Internet not only promotes the development and transformation of the whole tourism industry, but also needs to be actively combined with the development trend of tourism industry in the training of tourism management talents. With the help of Internet technology, students can also acquire a wide variety of learning resources, can understand the latest professional knowledge, and can independently learn on the network, so as to consolidate the knowledge learned in the offline curriculum, the theoretical knowledge of their own systematic integration. The development of Internet technology also points out the teaching goal and direction for colleges and universities to train tourism management professionals. This allows students in the learning process to make their professionalism to be systematically and effectively improved. Students' assessment of their ability to innovate is also not high, and the study is based on a questionnaire

\footnotetext{
*Corresponding author's e-mail: 739960103@qq.com
} 
survey of tourism students in a university, as shown in the following table:

TABLE 1 WHAT DO YOU THINK ARE YOUR MOST LACKING ABILITIES IN THE WORKPLACE?

\begin{tabular}{|c|c|c|c|}
\hline Problem & Options & Number & Proportion \\
\hline \multirow{4}{*}{$\begin{array}{c}\text { What do you think } \\
\text { are your most } \\
\text { lacking abilities in } \\
\text { the workplace? }\end{array}$} & The ability to innovate & 92 & $45.1 \%$ \\
\cline { 2 - 4 } & $\begin{array}{c}\text { Conguage expression } \\
\text { coordination skills }\end{array}$ & 28 & $13.73 \%$ \\
\cline { 2 - 4 } & $\begin{array}{c}\text { The ability to learn } \\
\text { independently }\end{array}$ & 52 & $7.84 \%$ \\
\cline { 2 - 4 } & Method capability & 4 & $25.49 \%$ \\
\hline & Other & 12 & $1.96 \%$ \\
\hline
\end{tabular}

\subsection{Theapplication of "Internet Plus" plays a guiding role in the teaching of tourism management}

In the process of training tourism professionals, colleges and universities must focus on the development trend of the times to innovate the teaching mode. With the continuous development of the Internet, the tourism management industry is also making progress, so higher vocational colleges in the process of training professionals in tourism management professionals must be combined with the development background of the domestic Internet

TABLE 2 DO YOU THINK THE CURRENT TEACHING MODEL OF COLLEGES AND UNIVERSITIES CAN MEET THE NEEDS OF TALENT TRAINING IN THE INTERNET-PLUS ERA? era:

\begin{tabular}{|c|c|c|c|}
\hline Problem. & Options. & Number. & Proportion. \\
\hline \multirow{2}{*}{\begin{tabular}{c} 
Do you think the current \\
teaching model of \\
colleges and universities \\
can meet the needs of \\
\cline { 2 - 4 }
\end{tabular}} & More satisfied & 20 & 9.8 \\
\cline { 2 - 4 } & Meet. & 60 & 29.41 \\
\cline { 2 - 4 } internet-plus era? & So so. & 104 & 50.98 \\
\hline
\end{tabular}

\section{UNDER THE BACKGROUND OF "INTERNET PLUS", THE TEACHING STATUS OF TOURISM MANAGEMENT MAJORS IN HIGHER VOCATIONAL COLLEGES}

\subsection{The professional development of tourism management is very rapid}

With the development of Internet technology and social and economic progress and upgrading, people pay more and more attention to the development of physical and mental health, tourism industry in recent years has shown explosive growth, people have gradually from the previous consumption of daily necessities to entertainment culture of spiritual consumption, especially in the tourism industry, the fast pace of the times and life pressure let people more and more pressure, the need for physical and mental relaxation is growing. This is also an important reason for the rapid development of the tourism industry. The development prospects of the tourism industry are very good, in such a social context, the demand for professionals in tourism management is also growing, tourism management professionals have also received widespread attention. With the increasing demand for tourism management professionals, tourism management professional positions are more and more detailed responsibilities, which also put forward higher to train professionals. In the course of classroom teaching, teachers should also have a certain understanding of Internet technology, especially the current tourism industry under the impetus of Internet technology development trends and development status, based on this tourism management major teaching objectives and teaching methods of adjustment. And for different regions of tourism differences to carry out targeted teaching, so as to ensure the effectiveness of teaching and teaching work. The following table shows whether universities can meet the training needs of tourism talents in the Internet-plus

requirements for tourism management professionals in higher vocational colleges, and with the number of candidates for tourism management professionals increasing year by year, the teaching of higher vocational colleges is also a great challenge.

\subsection{The combination of tourism management and the Internet is not deep enough}

Although teachers apply Internet technology to teaching classrooms through some Internet technology, most teachers in the classroom teaching is only the surface application of Internet technology, and did not carry out in-depth mining and use, which led to higher vocational colleges tourism management professional classroom teaching work and the Internet can not be effectively combined, can not play the advantages of the Internet role. In the eyes of most professional teachers, Internet technology is only a classroom aid, and does not delve into the scope of application of "Internet Plus" technology and technology. In this way, the innovation of the training model of tourism management professionals in vocational colleges and universities will be greatly hindered. 


\subsection{The demand for tourism management professionals has increased significantly}

The development of tourism industry is very rapid, people's demand for tourism is also increasing, at the same time, the community of tourism management professionals professional literacy requirements are getting higher and higher. The development of tourism industry has greatly driven the tourism-related professional examination, more and more people are very optimistic about the tourism management profession, with the increase in the number of tourism management professionals, tourism management professionals are also more and more demanding. Especially in the context of the "Internet Plus" tourism industry and its rapid development. Colleges and universities must attach importance to the innovative training of tourism management professionals.

\section{THE INNOVATIVE WAY OF TOURISM MANAGEMENT IN HIGHER VOCATIONAL COLLEGES UNDER THE BACKGROUND OF "INTERNET PLUS"}

\subsection{Teachers need to update their teaching philosophy}

Under the background of "Internet Plus", the teaching mode of traditional tourism management majors can't adapt to the training needs of talents in higher vocational colleges. Therefore, tourism professional teachers need to change their own teaching philosophy, teachers themselves must first actively integrate with the times, establish the Teaching Thinking of the Internet age, to have a basic understanding of the development trend of the tourism industry under the background of "Internet plus", based on a certain understanding and mastery of the Internet and then targeted teaching of students, so that students can timely understand the current development of the tourism industry, according to the needs of professionals in the tourism industry to improve students' professional knowledge and basic operating norms.

\subsection{Adjust the innovation model of talent development}

The training of tourism management professionals in higher vocational colleges needs to have a teaching goal and direction, colleges and universities need to have an innovative model of talent training, the establishment of this model can play a certain role in guiding and drawing lessons for the training of professionals, in order to achieve the effectiveness and systematic teaching, higher vocational colleges must realize the current "Internet plus" on the current tourism industry brought great impact, on this basis, the tourism management professional targeted teaching, the traditional teaching model to make certain adjustments, Combine the needs of the internet environment. In order to maximize the promotion of students' professional quality training.

\subsection{Optimize the content of the course}

Under the background of "Internet Plus", students have a good understanding of the Internet, in this Internet information age, higher vocational colleges must reform and innovate the tourism management profession, teachers also need to make certain innovations in teaching methods, through the combination with the Internet, the traditional teaching content innovation, targeted selection and innovation, for the development of tourism in the Internet environment for tourism management curriculum planning and explanation, in line with the development of the times.

\subsection{Pay attention to the practical training of students}

In higher vocational colleges, we can not only train and teach students' professional basic knowledge, but also need to train students' basic operational ability, even more so in tourism management major, tourism management major has strong practicality, and it is more necessary to train students' ability in practical work. Teachers can train students through targeted exercises, and through practical activities students can truly feel the requirements of professional ability at work, so that students can further understand and target their strengths and weaknesses. Teachers can also see the lack of students' ability and neglect in the teaching process through such teaching practice activities, which is a good observation opportunity for teachers, through the observation of students' performance can be targeted to improve their own teaching. In order to be able to carry out special explanation and improvement to students in the later teaching process.

\subsection{Professional training of the teacher team}

In the educational work of higher vocational colleges, the direct impact on students' learning efficiency is the professional quality and moral level of teachers, so colleges and universities must train professional teachers' professional knowledge level, and actively encourage teachers to improve themselves and social teaching practices, and also observe and guide teachers' moral literacy, starting from the teacher's point of hand, so as to establish a professional team of teachers, through the formation of a high-quality teaching team, Thus in the teaching process can make students' learning efficiency get the greatest improvement.

\section{CONCLUSION}

All in all, under the background of "Internet Plus", China's education field has been greatly developed and progressed, china's education field has also had a great impact, whether in the field of teacher teaching, or in the students' learning has played a great role. The traditional teaching methods obviously can't meet the needs and teaching requirements of tourism management professionals in the society at the time. Under the 
background of "Internet Plus", the training mode of tourism management professionals in higher vocational colleges must be reformed. The main way of innovation is to actively combine the Internet technology of the times, the effective application of Internet technology needs teachers to change their own teaching philosophy, the Internet technology in the teaching classroom to make full use of, improve the learning efficiency of students. At the same time, colleges and universities need to adjust their own talent training programs, in the context of the Internet to be aware of the development trend of tourism, so as to target the training of tourism management professionals. At the same time, we should optimize the curriculum system of tourism professionals, and we should not rely solely on the curriculum in the traditional teaching in the past to train professionals. Finally, it is also very important to train the teachers' team, because teachers are a group that has direct contact with students, and if we want to improve students' professional ability, we must realize the role of teachers in tourism management teaching in higher vocational colleges. Only in this way can we truly innovate the training model of tourism management professionals in higher vocational colleges under the background of "Internet Plus".

\section{REFERENCES}

1. Wang Lei, Li Yunfei. A Study on the Reform of Tourism Management Personnel Training Mode in Ningxia in the context of regional tourism [J]. Journal of Higher Education,2020(36):161-164.

2. Pan Hua, Wang Shanshan. On the Construction of a cooperative education model for tourism Management $[\mathrm{J}]$. Science Consulting (Science and Technology · Management),2020(12):31-32.

3. Chen Li. Research on ways to Deepen Schoolenterprise Cooperation for Higher Vocational Tourism Management Specialty under the background of cultural and Tourism Integration -- A Case study of Ningxia Vocational And Technical College [J]. Rural Economics and Science and Technology, 202, 31(22): 281-282.

4. Zhu Shengdong, Jiang Wei. Cultivation of independent learning ability of tourism Management majors under the background of "Internet $+"[\mathrm{~J}]$. Science and Education Wenhui (the following periodical),2020(11):124-126.

5. Zhang Ziyue. Practice of industry-education integration and Post internship Mode in tourism Management Major teaching in vocational colleges [J]. Journal of hubei open vocational college,2020,33(22):138-139.

6. Meng Shan. Research on the Training Mode of diversified talents for tourism Management major in Higher Vocational Colleges [J]. Qinghai Education,2020(11):34+36.

7. Tang Hua. Exploration on the construction of modern Apprenticeship for tourism Management Majors in higher vocational Colleges under the context of "Dual Subject and Two-way Interaction" [J]. Contemporary Tourism,202,18(32):95-96.

8. Yang Zhao, Zhu Qijing, Zhai Liuting, Yin Shoubing. A Survey on career Paths of College Tourism Management Graduates -- A Case study of Anhui Normal University [J]. Journal of hubei university of arts and sciences, 2020,41(11):45-50+57.

9. Sun Le. Research on the Development of five-year Higher Vocational Talent Training Program Based on modern Apprenticeship -- A Case Study of Tourism Management Major [J]. Research on Vocational Education,2020(11):12-17.

10. Chen Jianping. Construction of practical teaching System for application-oriented undergraduate Tourism Management major from the perspective of industry and education integration $[\mathrm{J} / \mathrm{OL}]$. Journal of Inner Mongolia agricultural university (social science edition): 1-9 [2020-12-26]. HTTP: / / http://kns.cnki.net/kcms/detail/15.1207.g.20201014. 1406.005.html.

11. Chen Siyu. Research on the Cultivation Path of Entrepreneurial Spirit for College Students majoring in Tourism Management [J]. Modern Vocational Education,2020(41):190-191.

12. Chen Siyu. The theory and practical application of tourism management teaching in colleges and universities based on case analysis [J]. Progress in chemical industry,2020,39(07):2921.

13. $\mathrm{Xu}$ Bin. Research on the Cultivation of Innovative and Entrepreneurial Talents for Tourism Management Under the background of "Internet +" [J]. Shanxi Agricultural Economics,2020(12):21-23.

14. Yin Jing. Research on the Design and Construction of tourism Management talent Training Program based on industry demand $[\mathrm{J}]$. Journal of wuhan polytechnic university,2020,19(03):54-59.

15. Jia Hongli. A preliminary study on the teaching reform of tourism management major in China in the context of school-enterprise cooperation [J]. Research on communication power,2020,4(17):140141 